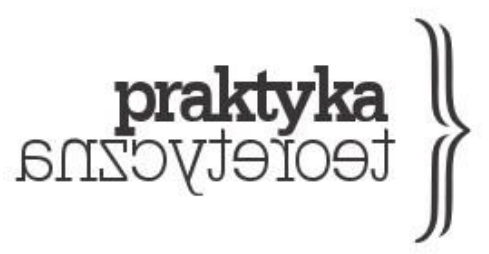

ISSN 2081-8130

DOI: $10.14746 /$ prt.2017.3.4 www.praktykateoretyczna.pl

\title{
OGÓLNY WZÓR DÓBR WSPÓLNYCH ${ }^{1}$
}

\author{
MASSIMO DE ANGELIS
}

\section{PRZEŁOŻYŁA: MARTA WICHA}

\begin{abstract}
Abstrakt: Niniejszy tekst jest przekładem rozdziału 5 książki Massimo De Angelisa Omnia Sunt Communia. On the Commons and the Transformation to Postcapitalism. Autor, inspirujacc się Marksowskimi formami cyrkulacji z pierwszego tomu Kapitału, podejmuje refleksję nad stosunkiem zależności, w jakim pozostają względem siebie kapitał i dobra wspólne. Efektem tych rozważań jest przedstawianie ogólnego wzoru dóbr wspólnych i tym samym wniknięcie w ukryte założenia stojące zarówno za formami cyrkulacji T-P-T, jak i P-T-P, które były dotąd ignorowane - również przez Marksa.
\end{abstract}

Słowa kluczowe: formy cyrkulacji, obieg kapitału, dobro wspólne, reprodukcja siły roboczej.

1 Tytuł pochodzi od redakcji. 


\section{Dwa obiegi}

W tekście tym badam źródła relacji między systemem kapitalistycznym a systemem dóbr wspólnych (the commons) - sposoby, w jakie gospodarka bądź rynki w istocie zakładaja dobra wspólne. Począwszy od lat 90. XX wieku w literaturze poświęconej dokonywanym przez kapitał grodzeniom dóbr wspólnych - często przyjmującym postać przemocowego wywłaszczania $\mathrm{z}$ zasobów utrzymywanych wspólnie oraz ustanawiania instytucji państwowych i ram prawnych służących ochronie wywłaszczeń - zakłada się, że dobra wspólne stanowią stały element rozwoju kapitału, a nie, jak utrzymywała tradycyjna literatura marksistowska, jednorazowe zdarzenie, inicjujące proces kapitalistycznego rozwoju (De Angelis 2004, Harvey 2003, Midnight Notes Collective 1992). Rozwój kapitalizmu wymaga utowarowienia rzeczy oraz przekształcenia ludzi w siłę roboczą możliwą do nabycia za płacę, ciagłego pozyskiwania kolejnych rzeczy i przekształcania ich w kapitał. W szczególności potrzebuje zaś wytwarzania zależności od formy towarowej stosunków społecznych, tak, by ludzie nie byli w stanie uwolnić się od kapitalistycznego przymusu pracy (Cleaver 1979). Jeżeli jednak kapitał, na różnych etapach swojego rozwoju, zawłaszcza napotkane dobra wspólne, to także one muszą reprodukować się i rozwijać. Dobra wspólne istniały na każdym z etapów rozwoju kapitału, jednak gdy kapitał zacznie postrzegać je jako granicę, którą należy przekroczyć, będzie dążył do wytworzenia strategii ich zawłaszczenia bądź wykorzystania. Skuteczność tej strategii uzależniona jest od względnej mocy, jaką dysponuje każda z przeciwstawnych sił społecznych. Z koegzystencją dóbr wspólnych i kapitału mamy zatem do czynienia przez cały czas, w każdym punkcie rozwoju i wzajemnych stosunków sił.

Istnieje jednak wciąż powracająca linia komunikacji i wymiany pomiędzy tymi dwoma systemami, kapitałem i dobrami wspólnymi, która powszechnie rozumiana jest jako „gospodarka”. Gospodarka, tak, jak rozumiemy ją dziś, opiera się na pieniądzu jako środku wymiany, zapłaty bądź jako mierniku wartości. Paradoksalnie, pieniądz jest również podstawa dwóch przeciwstawnych systemów, osadzonych w odmiennych sposobach istnienia, praktykach wartościowania oraz o różnych celach, którym służy produkcja i reprodukcja systemu. W swojej poprzedniej książce (De Angelis 2007a, 40-41) w kontekście sumy dążeń systemu kapitalistycznego, jego naglącej potrzeby akumulacji wraz ze strategicznymi problemami, związanymi z pokonywaniem napotykanych barier, posłużyłem się pojęciem dążenia do zachowania swojego istnienia (conatus of self-preservation). Marks, w pierwszym tomie Kapitału, pisał o tym jako o produkcji dla samej produkcji lub akumulacji dla samej akumulacji: „Akumulujcie, akumulujcie! Tak głosi Mojżesz i prorocy!” (Marks 1951, 641). Pojęcie conatus pochodzi od Spinozy, a ostatnio zostało podchwycone przez neurobiologa Antonio Damasio. Według niego, pomysł Spinozy ,interpretowany z korzystnej perspektywy 
czasu [...] zakłada, że żywy organizm jest tak skonstruowany, by utrzymać spójność swych struktur i funkcji wbrew zagrażającym życiu okolicznościom” (Damasio 2005, 35). Ja natomiast, w książce Beginning of History, przekładam te organiczne uwarunkowania na omówienie form, za pomocą których kapitał jako system utrzymuje spójność w obliczu licznych niebezpieczeństw „zagrażających [jego] istnieniu”, jakie niosą za sobą walki klasowe w obrębie dóbr wspólnych. W niniejszej książce chciałbym podjąć się odwrotnego zadania: rozważyć, w jaki sposób systemy dóbr wspólnych mogą zachować swoją spójność w obliczu licznych niebezpieczeństw „zagrażających istnieniu”, w głównej mierze wskutek inercji, odmowy oraz codziennej walki przeciwko kapitałowi. Aby wyjść z jednego systemu i wejść do innego, musimy tym samym znowu uderzyć do (albo uderzyć w) bramy pieniądza.

W tym celu posługuję się przede wszystkim Marksowskim narzędziem analitycznym i łączę ze sobą dwie formy cyrkulacji towarów. W czwartym rozdziale Kapitału Marks przeciwstawia sobie to, co nazywa najprostszą formą cyrkulacji towarów, ogólnemu wzorowi kapitału. Pierwsza z nich to T-P-T, a druga to P-T-P', gdzie T oznacza towar, P - pieniądz, zaś P' to ilość pieniędzy przewyższająca pierwotnie zainwestowaną sumę, włączając w to zysk. Rozróżnienie to pochodzi ze starożytności - jako pierwszy poczynił je Arystoteles, którego Marks przywołuje. Obie formy wyrażaja proces w jego trwaniu. Łącznik „-” pomiędzy literami symbolizuje przemianę, przejście z rąk do rąk (wymianę) między dwoma podmiotami: w przypadku T-P - towaru w pieniądz (sprzedaż), zaś P-T - pieniądza w towar (kupno). Obie formy opisują następstwo czasowe w danym miejscu lub miejscach. Jako że wszystkie wchodzące w skład tych procesów elementy, zarówno towar T, jak i pieniądz P, podlegaja przemianie w P lub $\mathrm{T}$, formy cyrkulacji nazywane sa równiė̇ obiegami. Wprowadzam kategorię obiegu, by zaledwie zasugerować istnienie ogólnego systemu takiego jak ramy przepływu kapitału (Meadows 2008), po to, by rozpocząć analizę poszczególnych dóbr wspólnych, wskazać punkty zwrotne, mocne i słabe punkty poszczególnych dóbr wspólnych w odniesieniu do kluczowych elementów ich obiegu; by porównać ten obieg z obiegami pieniądza, określić stopień istotności pieniądza w odniesieniu do samoreprodukujących się zasobów oraz by przyjąć strategiczną dla poszerzenia dóbr wspólnych perspektywę, stawiająca czoła ich otoczeniu bez ryzyka utraty ich organizacyjnej spójności.

Obie formuly zawieraja te same elementy i składają się na nie te same działania. Elementy wspólne dla obu formuł to towar T i pieniądz $\mathrm{P}$, natomiast działania, które formuły obejmuja, to sprzedaż i kupno. Występuja tu więc wszystkie podstawowe składniki, konstytuujące współczesne, neoliberalne wyobrażenia o gospodarce kapitalistycznej: kupno i sprzedaż, rynek.

W każdej z faz obu obiegów „przeciwstawiaja się sobie te same dwa elementy rzeczowe, towar i pieniądz - i dwie osoby w tych samych maskach ekonomicznych, nabywca i sprzedawca” (Marks 1951, 157). Ostatecznie, „każdy z obu tych ruchów okrężnych 
jest jednością tych samych przeciwstawnych faz i w obydwu wypadkach jedność ta dochodzi do skutku dzięki udziałowi trzech kontrahentów, z których jeden tylko sprzedaje, drugi tylko kupuje, trzeci zaś na przemian kupuje i sprzedaje”. (Marks 1951, 157). ${ }^{2}$

Obiegi te różnią się między sobą w co najmniej trzech aspektach.

Po pierwsze, tym, co odróżnia obieg T-P-T od obiegu P-T-P', jest odwrócona kolejność następowania po sobie dwóch faz. O ile prosta cyrkulacja T-P-T zaczyna się od sprzedaży, a kończy na kupnie, to obieg pieniędzy jako kapitału w P-T-P' zaczyna się kupnem, a kończy sprzedażą. W T-P-T zarówno punktem wyjścia, jak i celem jest towar, zaś w drugim z obiegów - pieniądz. W pierwszym obiegu pieniądze są pozyskiwane na rynku w ramach aktu sprzedaży towaru, po to, by poprzez zakup towaru powrócić do obiegu. W drugim natomiast, pieniądze sa wykładane po to, by je odzyskać. Pierwsza zatem różnica, jaka występuje pomiędzy prostą cyrkulacją towarową a tą kapitału, jest ich cel. W pierwszym wypadku celem jest zaspokojenie potrzeb, zaś pieniądze są zaledwie środkiem służącym do osiagnięcia tego celu. Celem drugiego obiegu jest pozyskanie zasobów pieniężnych: środek staje się tu celem.

Po drugie, choć w prostej cyrkulacji towarów po obu stronach znajdują się towary, i to o takiej samej wartości, to ,jako wartości użytkowe towary różnią się [..,] jakością”, jak na przykład ziemniaki i komputery. Jednakże:

\begin{abstract}
Inaczej ma się rzecz z cyrkulacją P-T-P. Na pierwszy rzut oka wydaje się ona pozbawiona treści, bo tautologiczna. Oba punkty krańcowe mają tę samą formę ekonomiczną. Oba są pieniądzem, a więc nie są jakościowo różnymi wartościami użytkowymi, gdyż pieniądz jest właśnie przeistoczoną postacią towarów, w której szczególne wartości użytkowe zostały zatarte. [...] Suma pieniędzy może się w ogóle różnić od drugiej sumy pieniężnej tylko swą wielkością. Proces P-T-P zawdzięcza więc swą treść nie jakiejś różnicy jakościowej swych krańcowych punktów, gdyż na każdym stoi pieniądz, lecz jedynie ich różnicy ilościowej. W rezultacie wycofujemy z cyrkulacji więcej pieniędzy niż wrzuciliśmy do niej na początku (Marks 1951, 159_ 160).
\end{abstract}

Ten przyrost pieniądza Marks nazywa wartością dodatkową (surplus value): „Pierwotnie wyłożona wartość nie tylko więc zachowuje się w cyrkulacji, ale żmienia w niej wielkość swej wartości, zwiększa się o pewną wartość dodatkowa, czyli pomnaża się. A ruch ten pržeksz̧tatca ja w kapital' (Marks 1951, 160). To spostrzeżenie prowadzi Marksa do omówienia pochodzenia wartości dodatkowej w produkcji wraz z korespondującymi z nią prawami rozwoju kapitalistycznego. W prostej formie cyrkulacji towarowej nie może pojawić się z kolei żadna

\footnotetext{
2 To na poziomie wspólnotowości teoretycy systemu, tacy jak Nikolas Luhmann (2007) moga przyznawać gospodarce funkcję wspólnotową, funkcję integrowania rozmaitych sił społecznych.
} 
wartość dodatkowa. P-T-P’ oraz T-P-T jawią się więc jako dwa różne równania chemiczne, o tych samych elementach, ale odmiennej kompozycji i strukturze, a przede wszystkim o odmiennych celach. Do pewnego stopnia to urzeczywistnianie tych różnych celów pozwala lub uniemożliwia reprodukcję właściwych im systemów, która może nastapić tylko przez powtórzenie tych przemian.

Docieramy tym samym do trzeciej, kluczowej różnicy. W prostym obiegu towarów:

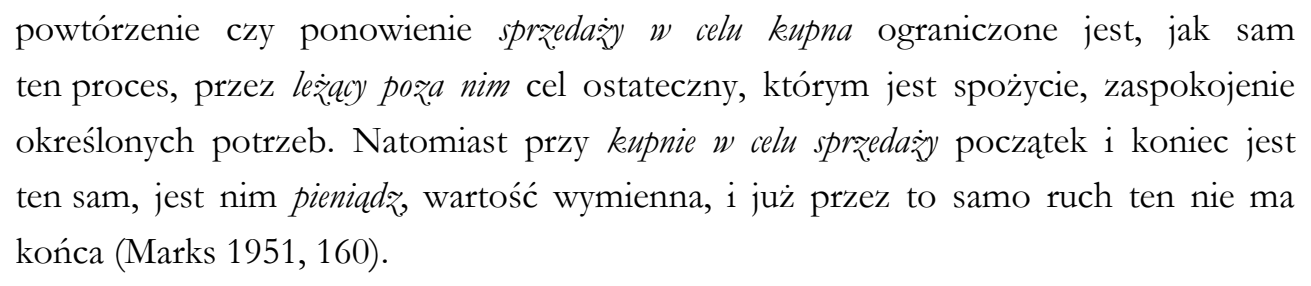

Mamy tu do czynienia z rozróżnieniem na ekonomię i chrematystykę, dokonanym już przez Arystotelesa, gdzie ta pierwsza jest sztuka gospodarowania w granicach zrównoważonego systemu potrzeb, druga zaś - dehumanizującą aktywnością polegającą na akumulacji pieniądza za pośrednictwem rynku, innymi słowy - na bogaceniu się.

W Polityce Arystoteles stwierdza, że chrematystyka dopuszczalna jest tylko wtedy, gdy do wymiany dochodzi bezpośrednio między producentem a kupcem za sprawiedliwą cenę; tym samym nie dochodzi do powstania nadwyżki. Innymi słowy, drobny handel, systemowo powiązany $\mathrm{z}$ gospodarstwem domowym, jest dozwolony. Z drugiej strony, niedozwolone jest, aby producent dokonywał zakupu, a następnie odsprzedawał towar konsumentom po wyższej cenie niż pierwotna, generując tym samym wartość dodaną. Pieniądz służyć ma zatem jedynie jako środek wymiany oraz miara wartości. Arystoteles opiera się na fundamentalnym rozróżnieniu pomiędzy dwiema instytucjami i ich celami, czy też przywołuje pole siłowe, w którym wszystkie siły zmierzają do jednego obszaru. Zdaniem Arystotelesa polis nakierowane jest na dobrobyt niezbędny dla dobrego życia i w tym celu gromadzi bogactwo w ramach gospodarstw domowych. Dobre życie jest zarówno celem, jak i granica absorpcji bogactwa pochodzacego z gospodarki domowej przez polis. W przypadku chrematystycznej pogoni za pieniądzem dla samego pieniądza celem, polem siłowym, w którym wszystkie siły zmierzaja w jedno miejsce, nie jest coś zewnętrznego wobec bogactwa, ale ono samo. W koncepcji tej zamiast dobrego życia mamy zaledwie egzystowanie, stawanie się narzędziem w pogoni za bogactwem.

Chrematystykę zilustrować można niekończąca się spiralą, przedstawioną na Rys. 1. Z każdym kolejnym wzrostem akumulacji pieniądza wydobyto jeszcze więcej surowców naturalnych, wyzyskano kolejnych robotników, by wytworzyć wartość dodatkowa; biosfera, rzeki, gleba zostały obciążone kolejnymi „efektami zewnętrznymi”, wzrosła liczba ludzi doprowadzonych do ubóstwa wskutek grodzeń, pośród robotników na całym świecie 
pojawiły się nowe podziały. Rzecz jasna należy zaznaczyć, że w ramach realnie zachodzących procesów ludzie cały czas stawiają opór, a nie są po prostu zdani na łaskę procesów kapitalistycznych.

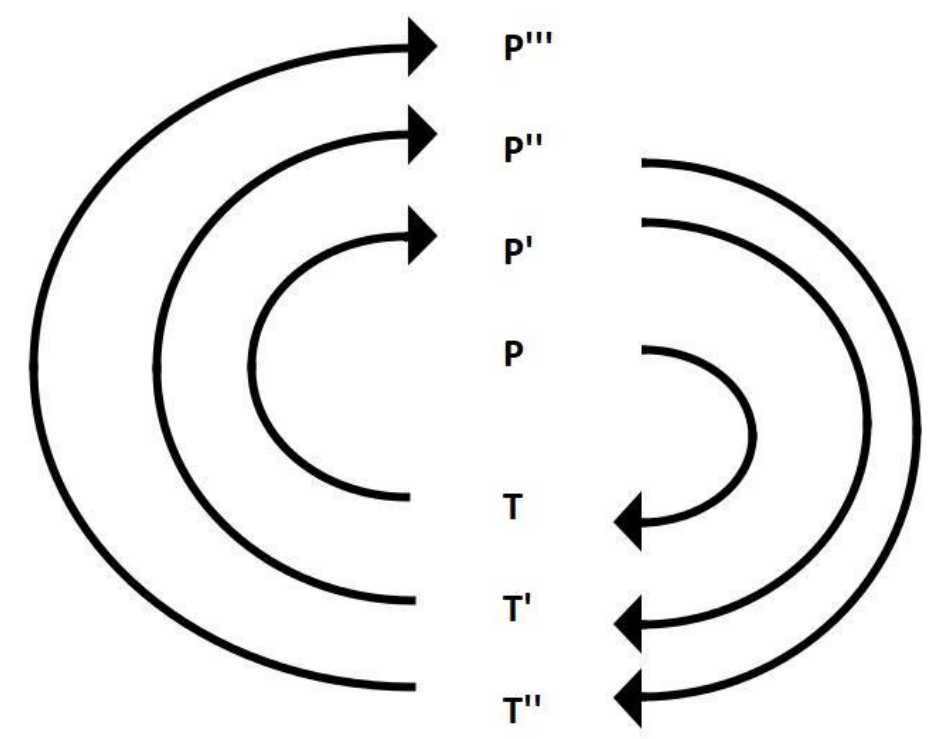

Rys. 1. Dążenie (conatus) kapitału do nieograniczonej ekspansji

Słowem „ludzie” (people) posłużyłem się tu w potocznym sensie. Czym innym jest pojęcie „lud” (people), które nie tylko redukuje różnice do jedności - choć w obrębie ludności istnieje cały szereg różnic (Hardt i Negri 2004, XIV). - ale też jest niewrażliwe tak na relacje wewnętrzne, jak i te z otoczeniem. Podobnie jest w przypadku pojęcia „masy” (the masses), którego istotą jest „niezróżnicowanie: wszystkie różnice zostają rozpuszczaja się i znikają w masie. Wielobarwność populacji blaknie i zmienia się w szarość. Masy te zdolne sa poruszać się zgodnie tylko dlatego, że stanowią „niewrażliwy na różnice, zuniformizowany konglomerat" (Hardt i Negri 2004, XIV). Hardt i Negri przeciwstawiają masom pojęcie wielości (multitude), „złożonej z niezliczonych wewnętrznych różnic, niesprowadzalnych do jedności czy pojedynczej tożsamości - różne kultury, rasy, etniczności, płcie i orientacje seksualne; różne formy pracy; różne style życia; odmienne światopoglądy; różne pragnienia. Wielość jest mnogościa tych wszystkich poszczególnych pragnień” (Hardt i Negri 2004, XIV). To dlatego wielość jest wielobarwna, a nie szara.

Pojęcie wielości pomija jednak dwie rzeczy. Po pierwsze, jest ono nieostre w odniesieniu do kapitału: obejmuje podmiotowości znajdujące się wewnątrz lub na zewnątrz kapitału, chociaż dla Hardta i Negriego, którzy nie dysponują systemowym rozumieniem społeczeństwa, nie istnieje zewnętrze kapitału i jego imperium. Ponadto, ponieważ ich koncepcja wielości „obejmuje potencjalnie wszystkich zróżnicowanych aktorów produkcji 
społecznej" (Hardt i Negri 2004, XIV), należy uwzględnić ich wzajemny stosunek sił - coś, co stanowi o ich zróżnicowaniu, a więc konstytuuje mnogość. Jeżeli projekt demokracji wielości pozostanie niedookreślony pod względem stosunków sił, ryzykujemy, że może nie pokrywać się ze sprawiedliwością społeczna, szeroko zakrojona redystrybucją bogactwa czy ekologiczną transformacją społecznej produkcji. Istnieje jeszcze jedno kluczowe rozróżnienie, na wielość i klasę robotnicza, która u Hardta i Negriego pojawia się tylko w odniesieniach do „klasy robotniczej” rozumianej jako przemysłowa klasa robotnicza, to jest homogeniczne podmiotowości istniejące w obrębie fabrycznej dyscypliny pracy. Uważam, że to ujęcie jest zwodnicze, ponieważ znaczna część literatury, od włoskiego feminizmu marksistowskiego po amerykański autonomizm, zwracała uwagę na to, że klasa robotnicza od zawsze dzieliła się na warstwy różniące się między sobą pod względem posiadanej sprawczości. Najważniejszy zaś podział to ten na robotników objętych stosunkiem pracy najemnej i tych pozostałych. W dalszej części powrócę jeszcze do analizy pojęcia klasy robotniczej oraz wielości, gdy wprowadzę dramatis personae, różnych aktorów występujących w ramach poszczególnych obiegów.

\section{Pozycje aktorów: kapitaliści i commonersi}

Marks podaje nam imię ,świadomego przedstawiciela” obiegu P-T-P', kiedy nazywa tego posiadacza pieniędzy ,kapitalistą”:

Jego osoba, a raczej jego kieszeń staje się punktem wyjścia i punktem powrotu pieniędzy. Obiektywna treść tej cyrkulacji - pomnażanie wartości jest jego subiektywnnym celem; jako kapitalista, czyli jako kapitał uosobiony, obdarzony wolą i świadomością, działa on o tyle tylko, o ile wyłączną pobudka jego operacyj jest przywłaszczanie w coraz to większych rozmiarach bogactwa abstrakcyjnego. Nie należy więc nigdy uważać wartości uṡyttoowej za bezpośredni cel kapitalisty. Nie jest też jego celem jednorazowy zysk, lecz jedynie nieustanny ruch osiagania zysku. To bezwzględne dążenia do bogacenia się, ta namiętna pogoń za wartością wymienną jest wspólna kapitaliście i zbieraczowi skarbu; gdy jednak zbieracz skarbu jest tylko obłakanym kapitalista, kapitalista jest racjonalnym zbieraczem skarbu. Gdy zbieracz skarbu dąży do nieustannego pomnażania wartości, usiłując ratować pieniądz przed cyrkulacją, rozumniejszy odeń kapitalista osiaga to samo, puszczając pieniądz wciąż na nowo w cyrkulację (Marks 1951, 162-163).

Sam Marks nie nazywa aktorów biorących udział w obiegu T-P-T, ale część tradycji marksistowskiej określa ich mianem drobnych handlarzy (petty traders). Tak jak kapitaliści staja się kapitalistami „o tyle tylko, o ile wyłączną pobudką [ich] operacyj jest przywłaszczanie 
w coraz większych rozmiarach bogactwa abstrakcyjnego" (Marks 1951, 162), tak drobni handlarze sa drobnymi handlarzami tylko jeśli wystawiają na rynku towary $\mathrm{w}$ celu zaspokojenia swoich potrzeb. Stąd, o ile o kapitalistach stanowią ich cele wyznaczane w stosunku do konieczności reprodukcji obiegu kapitału, dla drobnych handlarzy decydujące są środki, jakie wykorzystują oni na rzecz reprodukcji swojego systemu/obiegu potrzeb i pragnień. Z perspektywy ich dążeń nie są drobnymi handlarzami, ale przynależą do większej, społecznie zróżnicowanej kategorii aktorów, których ogólnie rzecz biorąc możemy określić commonersami. Rzecz jasna, przypisywanie im tej kategorii niekoniecznie koresponduje z ich autoidentyfikacja. Mógłbym bez końca przeprowadzać ankiety albo poświęcić miesiące badaniom etnograficznym mojego lokalnego rynku i najprawdopodobniej ani razu nie padłoby w nich słowo commoner. Ludzie zazwyczaj określają się przez swój zawód, wykonywaną pracę, status, role rodzinne, narodowość, płeć, religię, grupy etniczne, sympatie polityczne, zaangażowanie społeczne, a także klasę i samo bycie człowiekiem. Samoidentyfikacja jako commoner - dość powszechna w średniowiecznej Anglii - przecina wszystkie te poziomy i wymaga dzisiaj refleksji nad ludycznymi siłami, serdecznościa i wysiłkiem wkładanym w podtrzymywani interakcji pomiędzy różnorodnymi aktorami społecznymi oraz różnymi - jeśli nie przeciwstawnymi - społecznymi uwarunkowaniami, w tym takimi jak te kapitalisty.

$\mathrm{Na}$ tym poziomie ogólności tak kapitaliści, jak i commonersi definiowani sa w odniesieniu do obiegu, jakiemu daja początek, i do poziomu rynkowej wymiany. Ze względu na wszystkie kwestie praktyczne, tożsamość rzeczywistych aktorów jest dalece bardziej złożona. Posłużmy się przykładem: funkcja kapitalistów przejęta została przez menedżerów, oni z kolei zostali zastąpieni przez system zarządzania, który obejmuje coraz to nowe warstwy robotników najemnych i innych, by z powodzeniem wprowadzić nadzór niezbędny dla wytworzenia wydajności, która doprowadzi do maksymalizacji zysków.

Z drugiej strony definicji commonersa nie wyczerpuja drobni handlarze, choć drobni handlarze są commonersami. Stanie się to bardziej zrozumiałe w dalszej części, w której omawiam formułę dóbr wspólnych. W tym miejscu zaznaczę tylko, że pojęcie commoner jest bardziej ogólne niż robotnik bądź „proletariusz”. Pojęcie robotnika co do zasady rozumiane jest przez pryzmat pracy najemnej; utożsamienie to, choć często kwestionowane ze względu na pominięcie ogromu niepłaconej pracy niezbędnej dla reprodukcji i utrzymania kapitału, jest silnie zakorzenione (Cleaver 1979). W tym sensie określenie commoner obejmuje zarówno robotników najemnych, którzy sprzedają swoją siłę roboczą jak i nieopłacanych robotników, w tym przede wszystkim kobiety, których praca służy przeważnie reprodukcji siły roboczej. Robotnicy również są zatem drobnymi handlarzami, którzy w celu zaspokojenia własnych potrzeb sprzedaja towar - siłę roboczą. Dotyczy to również wykwalifikowanej siły roboczej im wyższe kwalifikacje, w tym wyższym stopniu koszty reprodukcji elementów składowych 
wyspecjalizowanej siły roboczej są postrzegane jako nakład mający na celu ułatwienie zatrudnienia (to jest, sprzedaży utowarowionej siły roboczej).

Proletariusz jest terminem szerszym niż robotnik i zazwyczaj obejmuje nie tylko podmioty społeczne pracujące w ramach systemu pracy najemnej, ale także tych wyłączonych z systemu produkcji, bezrobotnych $\mathrm{i}$ ich rodziny nieotrzymujące wynagrodzenia. Pojęcie to jest jednak trudne do pogodzenia ze współczesną fragmentaryzacją klasy robotniczej, złożonej z podmiotów o zróżnicowanym dostępie do wspólnych środków produkcji. Lacińskie korzenie tego słowa odnoszą proletariat do najniższej klasy obywateli rzymskich, dla których jedyną formą przysłużenia się państwu było posiadanie dzieci. W tradycji radykalnej jest to określony podmiot społeczny o szczególnym stosunku względem kapitału: wyzyskiwani lub zrewoltowani. Tak, jak w pojęciu proletariusz zawiera się termin robotnik, nie wyczerpując go, tak w pojęciu commoners mieści się definicja proletariusza.

Commonersów określa stosunek do kapitału, przez płacę lub jej brak, przez drobny handel lub ubóstwo; definiuje ich jednak także posiadana władza konstytuująca. Commonersi są podmiotami społecznymi, które - czego dowodzę w dalszej części - są zaangażowane w reprodukcję dóbr wspólnych i dla których ich stosunek z kapitałem jest częstokroć konieczny, ale nie wyczerpuje ich bytu społecznego i aktywności. To właśnie ta cecha czyni kategorię dóbr wspólnych interesująca z punktu widzenia dyskursu dotyczącego zmiany społecznej oraz commonersów, jak określam aktorów działających w ramach dóbr wspólnych. Dlatego też gdy spojrzymy na stosunki między commonersami a kapitałem, wystarczą nam pojęcia „klasa robotnicza” lub „proletariat”. Jeśli jednak chcemy uwzględnić także działania tej klasy na własna rzecz w odniesieniu do wielopostaciowej (re)produkcji odpowiednich warunków życia poza kapitałem, termin commoner stanowi lepsze rozwiąaniem. Obejmuje on bowiem zarówno relację względem kapitału, jak i dążenie do wytworzenia alternatyw.

\section{Obieg pieniężny kapitału}

Marks rozszerzył formułę obiegu kapitału w celu zwrócenia uwagi na aktywność społeczną, która zachodzi poza sferą cyrkulacji towarów, a wewnątrz produkcji kapitalistycznej. Podobnej operacji można dokonać w odniesieniu do prostego wzoru, chociaż sam Marks tego nie zrobił

W obiegu na Rys. 2 jak zwykle oznaczam kapitał pieniężny jako P, natomiast sumę wartości kapitału towarowego - czyli sumę wartości pieniędzy i towarów, rozumiana jako moment samonapędzania się kapitału- jako T. W procesach produkcji kapitalistycznej towar T przybiera dwie formy. Pierwsza, oznaczona jako Sr, oznacza siłę robocza - określony wyraz ludzkich mocy, zdolności do czegoś, materialnych lub niematerialnych, niezależny od poziomu kompetencji, umiejętności oraz złożoności pracy - sprzedawaną na rynku pracy 
za płacę. Druga forma, Śp, to środki produkcji rozumiane jako wszystkie „elementy natury” wykorzystywane w procesie produkcji, w tym zarówno surowy materiał do obróbki, jak i to, co powstało w wyniku szeregu złożonych przemian zachodzących w ramach produkcji społecznej: narzędzia, maszyny, komputery, budynki itd. Środki produkcji oraz siła robocza spotykają się w procesie produkcji ...P..., który z punktu widzenia zaangażowanych w nią osób to nic innego jak namacalny ciag praktyk życiowych, w ramach których siła robocza przekształca się w pracę abstrakcyjną, siłę społeczną podporządkowaną kapitałowi i jego mierze, wydatek ludzkiej energii (mózgu, mięśni i nerwów), spożytkowany, by wytworzyć nowy towar i zysk dla kapitalisty, zaś stany emocjonalne i życiowe doświadczenie robotników są podporządkowane kapitalistycznym praktykom wartościowania. Rzecz jasna, robotnicy moga stawiać opór, opóźniać prace albo wejść w otwarty konflikt. Ma to miejsce, gdy ich praktyki wartościowania ścierają się z tymi kapitału. Ten konflikt wpisany jest w każdy z momentów i w każde z przejść przedstawionych na Rys. 2 (Bell i Cleaver 2017: 10).

Zwieńczeniem procesu produkcji jest powstanie nowych towarów T', które następnie zostaną wprowadzone przez ich właściciela na rynek w celu ich sprzedaży za cenę P’ przewyższająca poniesione nakłady - a więc w celu osiąnięcia zysku $\Delta \mathrm{P}$.

Przedstawiony na Rys. 2 obieg kapitału powinien być traktowany nie jako ilustracja tego, co dzieje się w danym momencie, ale jako ciąg warunków niezbędnych dla kapitału szczególnej formy ludzkiej produkcji - by mógł reprodukować się w skali rozszerzonej. Osiagniecie go wymaga następowania po sobie kolejnych etapów. Kapitał odtwarza się bowiem tylko pod warunkiem realizacji wszystkich faz procesu. Skutkiem niedopełnienia tego warunku jest pojawienie się kryzysu (Bell i Cleaver 2017: 11). Proces pomnażania wartości faktyczna faza produkcji (...P...), w której energia życiowa wydatkowana jest w formie żywej pracy, przyczyniając się tym samym do zaistnienia konfliktu na poziomie praktyk wartościowania - zakłada, że kapitał jest w stanie znaleźć pracowników wyposażonych w określony zestaw umiejętności, którzy chcą i mogą sprzedać swoją siłę roboczą. Faza realizacji, T'-P', zakłada nastapienie wyzysku rzeczywistej pracy żywej i uprzedmiotowienie jej pod postacią wartości pieniężnej. Faza zakupu, P-T, zakłada, że pieniądz zostaje zgromadzony jako zakumulowane bogactwo, czy to za pomoca kredytu bankowego, czy finansowych zasobów przedsiębiorstwa, dostępnych i wprowadzanych do procesu jako inwestycja. Każdy z etapów uwzględnionych w tym ogólnym wzorze następuje w jednym, określonym momencie i przedstawia przemianę jakościową, a tym samym jest otwarty na potencjalne pęknięcie, kryzys, bądź przestój.

\section{$P-T\{S r ; S p\} \ldots . . . P \ldots . . T^{\prime}-P^{\prime}$}

Rys. 2. Rozszerzony obieg kapitału 
Ogólny obieg kapitału, przedstawiony niniejszym jako ciag sekwencji, mówi nam, co musi się wydarzyć, aby kapitał reprodukował się na coraz większą skalę, aby wciąż następował wzrost. Jak zauważyli Bell i Cleaver (2017), każdy moment obiegu kapitału jest momentem walki, co może tym samym wpływać na każdy z nich oraz/albo rozszerzać swoje oddziaływanie na kolejne, utrudniając kapitałowi podtrzymanie akumulacji. Walki o płace wpływaja na rentowność, podobnie jak te w ramach ...P... o czas pracy czy jej rytm. Inwestycja P-T jest natomiast zależna od spodziewanych zysków, a te z kolei określane są na podstawie kombinacji dotychczasowych zysków, od relatywnej „efektywności kosztowej” w przypadku przewidywanej zdolności do wydobycia pracy z robotników podczas ...P... w stosunku do robotników z innych miejsc, od wymuszenia zgody na restrukturyzację i redukcję zatrudnienia, od możliwości opłacalnego wydobycia surowców, a także od zdolności zwiększania społecznej wydajności poprzez budowę infrastruktury, która może zostać oprotestowana przez grupy ekologów i lokalne społeczności, i tak dalej. Z kolei moment realizacji T-P' zależy od możliwości sprzedaży, na którą z jednej strony wpływ ma siła nabywcza, z drugiej - walki toczone pomiędzy konkurującymi ze sobą kapitałami. Walki te odzwierciedlaja zróżnicowanie zdolności poszczególnych kapitałów do przekształcania swoich zatrudnionych bądź prekarnych robotników w obiekty produkcji (obiekty restrukturyzacji, mającej na celu zwiększenie wydajności bądź obiekty cięć płac) oraz możliwości zarządzania żywą pracą. Wzór z Rys. 2 pokazuje tym samym, że aby nastąiła akumulacja kapitalistyczna, konieczne jest podjęcie strategicznych działań w celu przezwyciężania kryzysów wpisanych w każdy z etapów. Wzory wyłaniające się z sumy tych strategicznych interwencji oraz celowych działań, zakładających określone praktyki wartościowania, są tym, co Marks nazywa „prawami” kapitalistycznego rozwoju, w których, jako takich, nie ma elementu determinizmu. Właśnie dlatego, że prawa te obejmują kontrtendencje, postrzegać je należy jako wynik strategii; każdy moment obiegu kapitału, w określonym punkcie w czasie, stanowi sytuację, w której różne podmioty społeczne o różnych pozycjach powołuja od istnienia odmienne i często wrogie siły społeczne o odmiennych dążeniach, co z kolei wpływa na całość wzoru obiegów.

\section{Sprzężenie obiegów}

Pieniężny obieg kapitału wiąże z obiegiem prostym niezliczona ilość połączeń. Ogólnie rzecz biorąc i co do zasady, każdy zakup i każda sprzedaż w obiegu kapitału może dokonać się jedynie za pośrednictwem aktorów obiegu prostego. Zainteresowanie Marksa budził przede wszystkim jeden uczestnik tego procesu, sprzedający w ramach niego określony towar - siłę robocza. Marks poprzestał jednak na analizie roli właściciela siły roboczej jako sprzedawcy tego towaru i jako robotnika w ramach pieniężnego obiegu kapitału. Całkowicie pomija 
natomiast proces produkcji tego szczególnego towaru, nawet w ogólnym zarysie. Marks, opisując pieniężny obieg kapitału, ignoruje to, co stanowi centralny, acz niewidzialny składnik kapitalistycznej produkcji, będący podstawą reprodukcji siły roboczej, a mianowicie - pracę reprodukcyjną, najczęściej nieopłacaną. Opierając się na badaniach radykalnych feministek w ramach ruchu „Płaca za Pracę Domową” (takich, jak Dalla Costa i James 1975; Cox i Federici 1976), pracę reprodukcyjną możemy postrzegać jako podobieg pieniężnego obiegu kapitału. W ten sposób możliwe staje się zobrazowanie relacji pomiędzy pracą reprodukcyjną a kapitalistycznym procesem pomnażania wartości, a także strategicznego znaczenia walk o reprodukcję dla całego obiegu. Ilustracją rzeczonej relacji jest Rys. 3, na którym obieg reprodukcji nadpisany jest nad pieniężnym obiegiem kapitału.

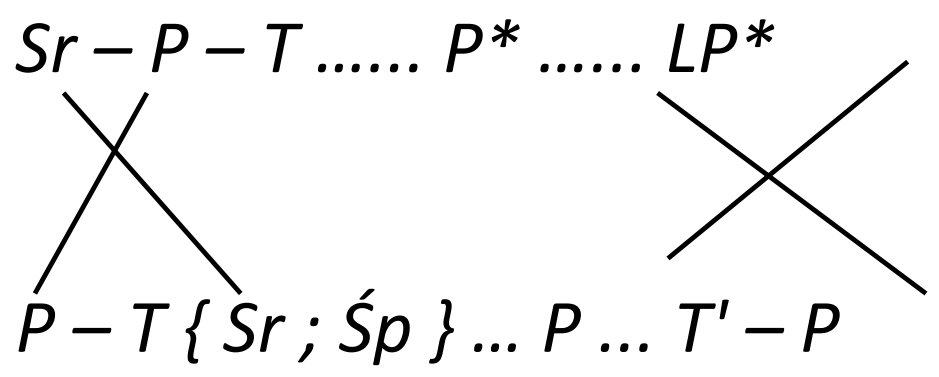

Rys. 3. Sprzężenie pomiędzy obiegami produkcji i reprodukcji

W obiegu reprodukcji pieniądz (P), uzyskany w zamian za siłę roboczą (Sr), wykorzystywany jest do zakupu towaru (T). Towary muszą być przetworzone w gospodarstwach domowych nakładem pracy P*. Ten wydatek pracy reprodukcyjnej umożliwia fizyczną i psychologiczna reprodukcję siły roboczej ( $\mathrm{Sr}^{*}=$ odtworzona siła robocza), co umożliwia jej ponowną sprzedaż. Mimo że w ramach obiegu reprodukcji podmiot wykonujący pracę reprodukcyjną nie jest określony, to jednak w warunkach dominacji stosunków patriarchalnych najczęściej praca ta przypada w udziale kobietom. W każdym razie, połączone obiegi kapitału wyznaczają jedynie szerokie ramy, w których umieścić można związek zachodzący między pracą reprodukcyjną i akumulacją kapitału. Górny obieg mógłby co do zasady służyć do zobrazowania innych form nieopłacanej pracy, takich jak praca studentów. Wtedy przepływ pieniędzy z dolnego do górnego obiegu mógłby przybierać formę transferów (stypendiów dla studentów) lub być likwidowany w sytuacji ich zniesienia, podczas gdy proces reprodukcji P* oznacza proces tworzenia tego, co ekonomiści określaja „kapitałem ludzkim"3.

\footnotetext{
3 W 1989 roku Harry Cleaver przekazał mi kilka maszynopisów wykładów na temat Marksa, które przygotował dla swoich uczniów. Tam po raz pierwszy zobaczyłem połączone obiegi kapitału i reprodukcji. To doświadczenie było absolutnym objawieniem, które rozbiło posiadane przeze mnie jeszcze resztki wiary
} 
Obieg przedstawiony na Rys. 3 może wydawać się przestarzały, gdyż reprodukcja siły roboczej odbywa się dziś wielu miejscach: w szkołach, szpitalach, placówkach opieki dziennej, urzędach pracy, ośrodkach szkoleniowych, więzieniach itd. Tym samym obieg na rysunku rozumiem w ogólnych kategoriach, nie ograniczam go do gospodarstwa domowego, choć to w nim odbywa się gros pracy reprodukcyjnej. Jeżeli przypisałoby się jej wartość pieniężna - chociażby tę obliczona przez Biuro Wysokiego Komisarza Organizacji Narodów Zjednoczonych ds. Praw Człowieka - wynosiłaby od 10 do 39\%PKB (UNHR 2013). Istotne jest tu podkreślenie wzajemnych zależności między obiegiem pieniężnym kapitału a obwodem reprodukcji siły roboczej. Przykładowo, spadek nakładów pracy reprodukcyjnej w $\mathrm{P}^{*} \mathrm{w}$ górnym obiegu przyczyni się do pogorszania jakości siły roboczej w ramach produkcji, a tym samym wpłynie na nią negatywnie. Kapitał może też przyjąć inną strategię i próbować zwiększyć nakłady pracy reprodukcyjnej P* przenosząc jej ciężar na pracowników nieopłaconych, na przykład poprzez redukcję wydatków na opiekę zdrowotna, tak by obniżyć płacę społeczna, a na gospodarstwo domowe przerzucić większą część pracy opiekuńczej. Taka modyfikacja analizy Marksa umieszcza w centrum pracę reprodukcyjną, którą głównonurtowa ekonomia uczyniła niewidoczną. Zwraca uwagę na obszar działalności człowieka pomijany przez główny nurt ekonomii (i głównonurtowy marksizm): pracę nieopłacona. Mechanizmy dyscyplinujące właściwe neoliberalizmowi, regulujące poprzez rynki społeczną kooperację, w coraz większym stopniu przenikaja także sferę pracy nieopłaconej. Szczególną rolę odgrywają w tym kontekście międzynarodowe przepływy kapitału finansowego, także zarządzanie długiem krajów w tzw. Trzecim Świecie, które razem niejako wymuszaja politykę globalnych oszczędności w zakresie wydatków socjalnych. Cięcia wydatków publicznych na opiekę nad osobami starszymi bądź opiekę nad dziećmi skutkują chociażby, zakładając niezmienność warunków, koniecznością wzrostu albo nakładu pracy niepłaconej w gospodarstwie domowym, albo nakładu bezpośredniej pracy zarobkowej, z której dochód umożliwi opłacenie wykonania pracy opiekuńczej.

Obieg na Rys. 3 pokazuje, że praca zarobkowa i niezarobkowa są momentami ciagu przekształceń kapitału, a tym samym stają się celami zgodnymi z kapitalistycznymi strategiami, obszarem kapitalistycznych praktyk wartościowania i walk wokół wartości. Wskazuje także, że kapitalizm $24 / 7$ pojawił się na długo przed wyłonieniem się postfordyzmu i „pracy komunikacyjnej”.

Tak więc strategie kapitału w sferze reprodukcji, takie jak kształtowanie systemu szkolnictwa, poziomu przyrostu populacji, czy przeznaczenia i wysokości wydatków na usługi

w ortodoksyjny marksizm. By złączyć oba obiegi, należy przyjąć radykalną perspektywę i zacząć myśleć w kategoriach złożoności obu systemów, uwzględniając zarówno płacowe, jak i nie związane z płaca aspekty naszego życia. O połączonych obiegach po raz pierwszy napisałem w De Angelis 2007, analizując złożoność kapitalistycznych stosunków walk w ramach globalnego kapitału. Teraz robię to, aby odkryć dobra wspólne ukryte w jego wnętrzu. 
publiczne - strategie, które obejmują dyscyplinę i kontrolę nad ciałami, czy (by posłużyć się pojęciem Foucaulta) które definiują domenę biopolityki - stanowią uzupełnienie strategii dotyczących produkcji, określających, które sektory gospodarki należy wzmacniać lub w jaki sposób regulować płacę społeczną. Z drugiej strony, towarzyszący cięciom w zakresie wydatków socjalnych oraz świadczeń rodzinnych wzrost transferów i dotacji dla przedsiębiorstw oddziałuje na sferę produkcji i reprodukcji pracy. Jednocześnie, walki toczone w ramach jednego obiegu mogą i często znajdą odbicie w innym, bądź też wskazują punkt oporu wobec strategii zapoczątkowanej w innym obiegu. Miało to miejsce w przypadku walk kobiet toczonych w latach 60. i 70.XX wieku, które wskutek podważenia i naruszenia podstaw państwa w państwie - rodziny patriarchalnej - wstrząsnęły całością struktury społecznej, która umożliwiała akumulację kapitalistyczną w epoce keynesowskiej po 1945 roku. Udało się to im, ponieważ stanowiły zagrożenie dla reprodukcji męskiej części siły roboczej, w jej szczególnych formach i praktykach, co z kolei przyczyniło się do zburzenia „pokoju społecznego” zrzeszonych w związkach zawodowych robotników, którego podstawę stanowił zbiorowo wynegocjowany wzrost płac i wydajności w ramach układu fordowskiego.

\section{Obieg dóbr wspólnych}

Warunkiem dalszego uogólniania analizy jest odejście od specyficznej formy reprodukcji siły roboczej i uznanie górnego obiegu z Rys. 3 za właściwy dla każdego towaru, to jest powrót do T-P-T w postaci T-P ... P ... P-T. W tej uogólnionej formie T-P-T opisuje nie tylko metabolizm reprodukcji siły roboczej w ogólnej postaci, lecz także obieg produkcji towarów obejmujący samozatrudnionych, drobnych producentów, rzemieślników, drobnych rolników ekologicznych, odzyskane fabryki, stowarzyszenia dostarczające wodę i tak dalej - również oni dostarczają swoje towary na rynek i sprzęgaja obiegi swego systemu opartego na potrzebach z gospodarką. Jako że ludzkie potrzeby i pragnienia moga znaleźć zaspokojenie $\mathrm{w}$ wielu formach społecznych $\mathrm{i}$ wielu formach organizacji, jeżeli spojrzymy w jeszcze szerszej perspektywie, zauważymy, że forma obiegu T-P-T sama w sobie stanowi zaledwie etap reprodukcji społecznej. Istotność tego momentu, jego intensywności i skali, jest kwestią całkowicie historyczną i zależną od okoliczności. Sednem jest to, że w przeciwieństwie do obiegu kapitału, prosty obieg towarowy jest środkiem, a tym samym czymś dającym się regulować w odniesieniu do zewnętrznego kontekstu, do struktury potrzeb i pragnień, jak również do zasobów możliwych do wykorzystania w nieutowarowionych formach (na przykład dzięki współdzieleniu, obwodom daru lub transferom administracyjnym). 
W tym znaczeniu towary w obiegach T-P-T stanowią element społecznego procesu produkcji, który odbywa się równolegle wobec szczególnych form oraz sposobów kooperacji, produkcji nietowarowej, i jest z nimi społecznie powiązany. Pozwala nam to na umieszczenie T-P-T jako sekwencji w ramach szerszego obiegu, określanego mianem obiegu dóbr wspólnych (the commons circuit), co ilustruje Rys. $4^{4}$.

Rys. 4 przedstawia konstytutywne elementy dóbr wspólnych (Dw): wspólne zasoby czy też wspólne bogactwo (Wb) oraz powiązaną z nimi społeczność (S) - mówiąc krótko, stowarzyszenie. W tym momencie abstrahujemy od tego, jak powstało stowarzyszenie, czy przez pokrewieństwo (jak w przypadku andyjskich ayllu), sympatie polityczne (jak w przypadku centrów społecznych znanych z Europy), bliskość terytorialną (jak stowarzyszenia sasiedzkie w USA), cyber-spotkanie w ramach projektu tworzenia oprogramowania (tak jak ma to miejsce w przypadku sieci P2P), lokalne tradycje (jak w wiosce indiańskiej), czy poprzez wybór oparty na uczuciach i emocjach (jak dzieje się w przypadku wspólnych gospodarstw domowych czy sieci koleżeńskich w Europie). Poszczególne rodzaje dóbr wspólnych różnią się od siebie między innymi w zakresie formy ustrukturyzowania ich elementów, na które z kolei składają się materialne i niematerialne aspekty. Aspekty materialne to aspekty biofizyczne: ludzkie ciała składające się na S, cechy środowiska, które współdzielą jako Wb, bądź jakiekolwiek współdzielone narzędzia, technologie czy budynki. Niematerialne elementy co prawda trudniej uchwycić, ale są równie rzeczywiste i wywołują namacalne skutki: kulturowy horyzont społeczności, posiadana wiedza, dyspozycje i wszystko to, co zostało opisane w rozdziale 3.

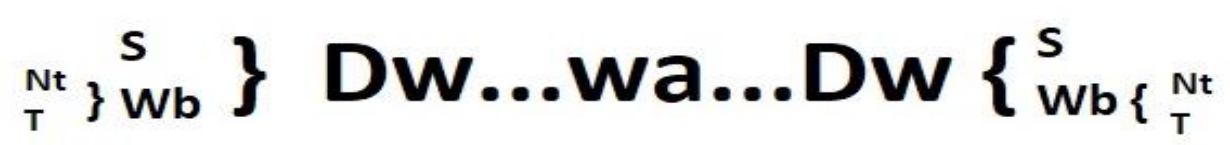

\section{Rys. 4. Obieg dóbr wspólnych}

Również elementy konstytutywne dóbr wspólnych tworzą się i są tworzone przez poszczególne relacje między nimi. Stowarzyszenie to pewna całość, złożona z relacji (zwyczajów, ról, konfliktów, reguł, norm i instytucji) i elementów (ludzi). Na znaczną część Wb składa się zbiór nie-ludzkich form życia, biorących udział w określonych procesach ekologicznych (to, co nazywamy „ziemią, „woda”, „powietrzem”, „ekosystemem” itd.) oraz ich materialnego podłoża (kamieni, minerałów itd.). Występowanie na początku

\footnotetext{
${ }^{4}$ Idea obiegu dóbr wspólnych, wzorowanego na obiegach kapitałowych nie jest nowa. Dla mnie inspiracją była prezentacja Nicka Dyer-Witheforda (2006) w Cambridge, dotycząca rozwijanych tu tematów.
} 
i na końcu procesu elementu Dw (dóbr wspólnych) pokazuje, że dobra wspólne są w swej istocie jednością stowarzyszonej społeczności (S) i jej wspólnego bogactwa (Wb).

Wb z kolei dzieli się na dwa główne typy: na te, które są ze sobą powiązane w ramach sfery tego, co wspólne, czyli o postaci nietowarowej (NT) oraz te, które muszą zostać nabyte na rynku jako towary (T). Aby uzyskać dostęp do środków pieniężnych, umożliwiających nabycie towarów, członkowie wspólnoty muszą albo wejść na rynek w roli nabywcy (lewa strona wzoru), sprzedawcy (prawa strona wzoru) bądź uzyskać środki za pomocą zewnętrznego źródła finansowania (państwa lub innej organizacji, np. NGO).

Wreszcie, środkowy punkt Rys. 4, to jest wa, a więc wspólna aktywność jest konieczna do odtworzenia się dóbr wspólnych w podstawowej formie.

\section{Dalsze refleksje}

Przedstawiony na Rys. 4. obieg dóbr wspólnych wywodzi się z dwóch różnych obiegów pieniądza, zakorzenionych w odmiennych filozoficznych i ekonomicznych tradycjach. Ani Arystoteles, twórca rozróżnienia na oeconomia i chrematystykę, ani Marks, który opracował schemat obiegu kapitału w celu zidentyfikowania źródła wyzysku, ani rozumiejący różnice pomiędzy dwoma obiegami Keynes ${ }^{5}$ - żaden $z$ nich nie odważył się postawić pytania o to, co kryje się za obiegami T-P-T i P-T-P'. Jak już zostało wspomniane, zasługę tę przypisać należy marksistowskim badaczkom feministycznym oraz aktywistkom z lat 70. XX wieku, chcącym pokazać, że niewidzialna praca kobiet wykonywana w sferze prywatnej na rzecz reprodukcji siły roboczej odtwarza stosunki patriarchalne w rodzinie, gdzie mężczyzna odgrywa rolę nadzorcy i kontroluje wykonywanie prac domowych przez kobiety. Wpływ pracy domowej na wartość siły roboczej stanowił podstawowy argument w międzynarodowej kampanii na rzecz płacy za pracę domowa. W zakresie, w jakim po II wojnie światowej proletariacka rodzina była funkcjonalna dla procesu akumulacji kapitału i keynesowskiego układu pomiędzy robotnikami fabrycznymi (głównie mężczyznami) a związkami zawodowymi, relacje władzy z fabryki były powielane w sferze domowej i w rodzinie - co nie mieści się w formie cyrkulacji z Rys. 4 - w efekcie czego rodzina została przekształcona w zdeformowane i skorumpowane dobro wspólne (Hardt i Negri 2012), w której mężczyzna funkcjonuje jako przełożony kobiety. Obecnie mamy do czynienia z procesem przeobrażania się wielu rodzin $\mathrm{w}$ inny rodzaj skorumpowanego dobra wspólnego - w rodzinę neoliberalną

\footnotetext{
5 Omówienie poglądów Keynesa na temat Marksa: zob. Dillard (1984, 1987), Aoku (2011) i Bertocco (2005). Keynes miał napisać: „[Marks] zwrócił uwagę, że natura produkcji w rzeczywistym świecie nie jest [...] sprawą obiegu T-P-T, tzn. wymianą towaru (lub nakładu sił) na pieniądze w celu otrzymania innego towaru (lub nakładu sił). Może to stanowić punkt widzenia prywatnego konsumenta, ale nie jest to podejście biznesowe, z którym mamy do czynienia w przypadku formuły P-T-P, tj. zamianie pieniędzy na towar (lub nakład sił) w celu uzyskania większej ilości pieniędzy” (cyt. w Bertocco 200, 494 p4).
} 
(Garrett, Jensen, Voela 2016; Barbagallo 2016): przedsiębiorstwo o wysokim podwójnym dochodzie, konkurujące z innymi o wszystko: karierę, najlepsze szkoły, najlepszych opiekunów, najlepsze dzielnice. Neoliberalne rodziny biorą udział w walce konkurencyjnej, która zakłada sukces najbogatszych, podczas gdy najbiedniejszych skazuje na niskiej jakości szkoły, usługi i mieszkania. Przedstawiony na Rys. 4 schemat wskazuje jednak, że mikrodobro wspólne, jakim jest rodzina, to coś więcej niż patriarchalne czy neoliberalne ujarzmienie. W zakresie, w jakim obieg dóbr wspólnych jest (re)produkowany poprzez wartości i praktyki alternatywne względem patriarchatu czy neoliberalizmu, zakorzeniony we wzajemnym wsparciu, miłości i serdeczności obieg dóbr wspólnych (re)produkuje dobro wspólne w jego nieskorumpowanej postaci.

Zasada ta dotyczy także dóbr wspólnych większych niż rodzina. Można sobie wyobrazić dużą różnorodność dóbr wspólnych, organizowanych w sposób ujęty w formule z Rys. 4, od gospodarstw domowych po gospodarstwa rolne, od stowarzyszeń lokalnych po samoorganizujące się ośrodki społeczne i miejsca produkcji kultury ${ }^{6}$. Podajmy tu prosty przykład przepływów zasobów na podstawie nocy w Forte Prenestino, samoorganizującym się centrum społecznym w Rzymie, które zajęło ponad trzydzieści lat temu starą twierdzę, gdzie, pośród wielu różnych aktywności, organizowane są koncerty oraz wydarzenia kulturalne i polityczne. Obieg nietowarowy reprezentuje praktyki relacyjne, kulturowe i wiedzę, które zostały wcześniej wygenerowane w poprzednich obiegach i następnie wprowadzone jako zasoby zreprodukowane (i rozwinięte). „Wyjściowe” lub reprodukowane zasoby pojawiają się przed „wejściowymi” zasobami następnego cyklu, ponieważ zasoby kulturowe także są reprodukowane lub odtwarzane. Dzieje się tak również dlatego, że proces produkcji kultury i wiedzy społeczności implikuje rozwój w każdym cyklu. Ów proces nie jest statycznym powtórzeniem procedur, ma dynamiczny charakter. Każde nowe „wejście” niekoniecznie jest tożsame $\mathrm{z}$ poprzednim. Dane wyjściowe, które są zarazem warunkiem koniecznym każdego wejścia, mogą różnić się od tych poprzednich. Prawdopodobieństwo zróżnicowania wzrasta w sytuacji, w której rozważana wspólnota - w dużej mierze także wspólnota polityczna - znajduje się we wrogim środowisku (grupy faszystowskie, obojętność, czy wręcz wrogość otaczających społeczności, zawłaszczające państwo). Wrogie środowisko wymusza strategie adaptacyjne, powodując tym samym rozwój dóbr wspólnych. Także wszystko to, co materialne, co wrzucamy lub znajdujemy we „wspólnym garnuszku”, również niektóre podstawowe zasoby materialne, przynależące do tych obiegów, odtwarzane są wspólnotowo po każdej imprezie przez naprawy, sprzątanie i ponowną aranżację (krzesła, toalety, ławki, stoliki, instrumenty muzyczne, światła, napoje, żywność, broszury, inne

\footnotetext{
6 Centri sociali (centra społeczne) często powstają w wyniku zajmowania przez młodych aktywistów opuszczonych, starych budynków i przekształcenia ich w centra polityczne, kulturalne i rekreacyjne. Na tego rodzaju doświadczeniu opiera się Mudu (2004).
} 
materiały polityczne, które trzeba było wyprodukować). W skład opisywanych procesów wchodzą także obiegi towarowe. Posiadają one jednak charakter T-P-T, który ogranicza rynki do metabolicznej funkcji reprodukcji społecznej. Stowarzyszeni piwowarzy sprzedaja na imprezach swój produkt, ale jednocześnie mogą też być częścia grupy zarządzającej przestrzenią bądź mogą ich łączyć z innymi związki wykraczające poza wymianę rynkową. Tak więc obwody rynkowe uwikłane są we wspólnotowe aktywności (wa) w ramach większych systemów. Część zasobów pieniężnych, uzyskanych ze sprzedaży piwa, może zostać skumulowana z zasobami innych producentów i przeznaczona na zakup materiałów użytkowanych w ramach dóbr wspólnych, zachowana część zasili natomiast obieg domowego dobra wspólnego tych producentów. Analiza obiegów systemowych i wzajemnych oddziaływań wszystkich możliwych strumieni i zasobów pozwala zrozumieć różnego rodzaju procesy, granice między poszczególnymi systemami stają się jasne, a wytyczanie granic, w tym ograniczeń podmiotowych oraz napięć związanych z ich przezwyciężaniem, staje się przedmiotem ustaleń między commonersami. 


\section{Wykaz literatury}

Aoki, Masato. 2001. „To the Rescue or to the Abyss: Notes on the Marx in Keynes.” Journal of Economic Issues 35(4): 931-54.

Arystoteles. 2008. Polityka. Tłum. Ludwik Piotrowicz. Warszawa: PWN.

Bell, Peter i Harry Cleaver. 2017. Teoria krysysu jako teoria walki klas. Tłum. Krzysztof Król. Poznań: Wydawnictwo A+.

Barbagallo, Camille. 2016. The Political Economy of Reproduction: Motherhood, Work and the Home in Neoliberal Britain. PhD thesis: University of East London.

Cox, Nicole i Silvia Federici. 1976. Counter-planning from the Kitchen: Wages for Housework: A Perspective on Capital and the Left. New York: New York Wages for Housework Committee.

Dalla Costa, Mariarosa i Selma James. 1975. The Power of Women and the Subversion of the Community. Bristol: Falling Wall Press.

Cleaver, Harry. 2011. Polityczne czytanie Kapitału. Tłum. Iwo Czyż. Poznań: Oficyna Wydawnicza Bractwa Trojka.

Damasio, Antonio. 2005. W poszukiwaniu Spinozy. Radość, smutek i czujacy mózg. Tłum. Janusz Szczepański. Poznań: Rebis.

De Angelis, Massimo. 2004. „Separating the Doing and the Deed: Capital and the Continuous Character of Enclosures". Historical Materialism, 12(2): 57-87.

De Angelis, Massimo. 2007. The Beginning of History: Value Struggles and Global Capital. London: Pluto.

Deb, Debal. 2009. Beyond Developmentality: Constructing Inclusive Freedom and Sustainability. London: Earthscan.

Dillard, Dudley. 1984. „Keynes and Marx: A Centennial Appraisal.” Journal of Post Keynesian Economics 6(3): 421-432.

Dillard, Dudley. 1987. „Money as an Institution of Capitalism.” Journal of Economic Issues 21(4): 1623-1647.

Dyer-Witheford, Nick. 2006. The Circulation of the Common. Paper presented at Immaterial Labour, Multitudes and New Social Subjects: Class Composition in Cognitive Capitalism, 29-30 April, King's College, University of Cambridge. www.fims.uwo.ca/people/ faculty/dyerwitheford/commons2006.pdf.

Garrett, Roberta, Tracy Jensen i Angie Voela (red.). 2016. We Need to Talk about Family: Essays on Neoliberalism, the Family and Popular Culture. Cambridge: Cambridge Scholars Publishing.

Hardt, Michael i Antonio Negri. 2004. Multitude: War and Democracy in the Age of Empire. New York: Penguin.

Hardt, Michael i Antonio Negri. 2012. Rzecz-pospolita. Poza wtasność prywatna i dobro publiczne. Tłum. Piotr Juskowiak, Agnieszka Kowalczyk, Mikołaj Ratajczak, Krystian Szadkowski, Maciej Szlinder. Kraków: Korporacja Ha!art.

Harvey, David. 2003. The New Imperialism. Oxford: Oxford University Press.

Harvie, David i Keir Milburn. 2004. Moments of Excess. Leeds: Free Association.

Luhmann, Niklas. 2007. Systemy społeczne. Tłum. Michał Kaczmarczyk. Kraków: Nomos.

Marks, Karol. 1951. Kapitat, t. 1. Warszawa: Książka i Wiedza.

Meadows, Donella. H. 2008. Thinking in Systems. London: Earthscan.

Midnight Notes Collective. 1992. „New Enclosures.” W Midnight Notes, przedruk w The Commoner 2, September 2001, www.commoner.org.uk/02midnight.pdf. 
Mudu, Pierpaolo. 2004. „Resisting and Challenging Neoliberalism: Development of Italian Social Centers." Antipode 36 (5): 917-941.

Okia, Opolot. 2012. Communal Labour in Colonial Kenya: The Legitimisation of Coercion. New York: Palgrave Macmillan.

P2P Foundation. 2010. Section 2, Stefan Meretz. Commons - Typology, http://p2pfoundation.net/Commons_-_Typology.

UNHR (2013). Unpaid Work, Poverty and Women's Human Rights, www.ohchr.org/EN/Issues/Poverty/Pages/UnpaidWork.aspx. 
Massimo De Angelis - uzyskał doktorat w zakresie ekonomii na University of Utah w 1995 roku i Laurea (włoski odpowiednik magisterium) z dziedziny nauk politycznych na Universita’ Statale di Milano w 1985 roku. Specjalizuje się w krytycznej ekonomii politycznej. Jest autorem wielu publikacji na temat teorii wartości, globalizacji, ruchów społecznych i politycznego czytania ekonomii. Jego ostatnia ksiazżka, Omnia Sunt Communia: On the Commons and the Transformation to Postcapitalism, ukazała się w 2017 roku nakładem wydawnictwa Zed Books.

\section{DANE ADRESOWE:}

Massimo De Angelis

School of Law and Social Sciences (LSS)

University of East London Docklands Campus University Way

London E16 2RD

EMAIL: m.deangelis@uel.ac.uk

CYTOWANIE: De Angelis, Massimo. Ogólny wzór dóbr wspólnych. Praktyka Teoretyczna 3 (25): 113-133.

DOI: $10.14746 /$ prt.2017.3.4

\section{AUTHOR: Massimo De Angelis}

TITLE: The General Formula of the Commons

ABSTRACT: This article is in fact a translation of chapter 5 of Massimo De Angelis' Omnia Sunt Communia. On the Commons and the Transformation to Postcapitalism. Inspired by the formulas of circulation, the author undertakes an examination of the co-dependency relationship between capital and the commons. In the end he presents a general formula of the commons and, at the same time, the hidden side of the C-M-C and M-C-M formulas, which hitherto had been overlooked, even by Marx.

KEYWORDS: forms of circulation, circulation of capital, the commons, reproduction of labour power. 